\title{
5-(Perylen-3-ylethynyl)uracil Derivatives Inhibit Reproduction of Respiratory Viruses
}

\author{
Y. V. Nikolayeva ${ }^{a}$, E. A. Ulashchik ${ }^{b}$, E. V. Chekerda ${ }^{a}$, A. V. Galochkina ${ }^{a}$, N. A. Slesarchuk ${ }^{c, d}, e$, \\ A. A. Chistov ${ }^{c, e}$, T. D. Nikitin ${ }^{c, d}$, V. A. Korshun ${ }^{c, e, f, ~}$, V. V. Shmanai ${ }^{b}$, \\ A. V. Ustinov ${ }^{c, e}$, and A. A. Shtro ${ }^{a}$ \\ ${ }^{a}$ Smorodintsev Research Institute of Influenza, St. Petersburg, 197376 Russia \\ ${ }^{b}$ Institute of Physical Organic Chemistry of the NAS Belarus, Minsk, 220072 Belarus \\ ${ }^{c}$ Shemyakin-Ovchinnikov Institute of Bioorganic Chemistry, Moscow, 117997 Russia \\ ${ }^{d}$ Department of Chemistry, Moscow State University, Moscow, 119991 Russia \\ ${ }^{e}$ Department of Biology and Biotechnology, National Research University Higher School of Economics, \\ Moscow, 117312 Russia \\ ${ }^{f}$ Gause Institute of New Antibiotics, Moscow, 119021 Russia \\ Received November 13, 2019; revised November 25, 2019; accepted December 1, 2019
}

\begin{abstract}
In this work, we describe the synthesis of 5-(perylen-3-ylethynyl)uridine and its ability to effectively inhibit the replication of respiratory disease pathogens in cell culture, namely: influenza A virus (IVA); type 3 parainfluenza virus (PIV-3); and human respiratory syncytial virus (RSV). Related known compounds were also analyzed: 5-(perylen-3-ylethynyl)-2'-deoxy-uridine; 5-(perylen-3-ylethynyl)-arabino-uridine; and 1-carboxymethyl-3-pivaloyloxymethyl-5-(perylen-3-ylethynyl)uracil.
\end{abstract}

Keywords: perylenylethynyluracil compounds, nucleosides, non-nucleoside derivatives, antiviral activity, influenza A virus, respiratory viruses

DOI: $10.1134 / \mathrm{S} 1068162020030139$

\section{INTRODUCTION}

Respiratory diseases are a significant problem affecting the health of the world's population. One of the most dangerous among them is the influenza virus, which causes annual epidemics (about one billion cases, up to 5 million of which are severe, and 0.65 million deaths) $[1,2]$. Historically, it has caused several global pandemics, including the 1918 'Spanish flu,' which killed about 50 million people [3]. The epidemiological danger surrounding the influenza virus lies in its high mutational variability and the diversity of its environmental routes of circulation [4].

Although the pharmaceutical market is filled with a variety of cold and flu products, most are directed at symptoms, and few feature any direct inhibitory effect on the pathogen. Three groups of antiviral drugs are etiotropic: M2-channel blockers (amantadine, remantadine); neuraminidase inhibitors (oseltamivir, zanamivir); and protease inhibitors (baloxavir marboxil and faviperavir). Drugs in the first group have

\footnotetext{
${ }^{1}$ Corresponding author: phone: +7 (499) 724-67-15; e-mail: v-korshun@yandex.ru.
}

now lost their potential as influenza agents due to high resistance to them among circulating strains [5]. Drugs in the second group are still the most effective, but the emergence and spread of resistant strains is possible. For example, in 2008, 68\% of influenza A (H1N1) virus isolates in Norway were resistant to oseltamivir [6]. The third group of anti-influenza agents is not yet registered in Russia. It should be noted that all three groups of drugs, as well as the latest drugs under development [7], are aimed at protein targets.

Although they cause less mortality than the influenza virus, the parainfluenza (PIV) and respiratory syncytial (RSV) viruses are nevertheless dangerous. High-risk patients (preschool children, the elderly, persons with immune disorders) are especially vulnerable. There are no etiotropic drugs to treat illness caused by these pathogens, only symptomatic treatments. Thus, there is an urgent need to develop new, effective means of respiratory virus control. Preparations featuring entirely new mechanisms of action, relative to existing drugs, are of special interest. 


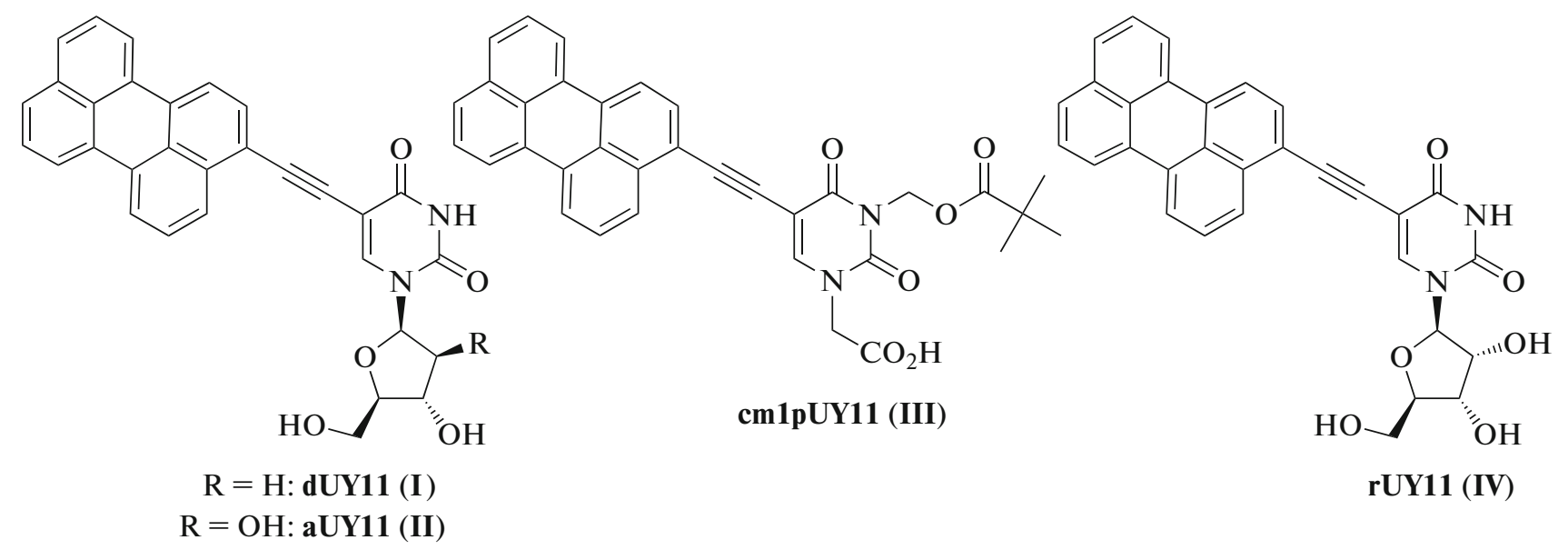

Previously, we found that perylene derivatives of uracil nucleosides dUY11 (I) and aUY11 (II) are highly active against a broad spectrum of enveloped viruses: herpes simplex type 1 and type 2; Sindbis; hepatitis C; vesicular stomatitis [8-11]; tick-borne encephalitis [12]; African swine fever [13]; and the influenza A virus serotypes $\mathrm{H} 1 \mathrm{~N} 1$ and $\mathrm{H} 3 \mathrm{~N} 2$ [10]. Despite the formal nucleoside structure, there is evidence in favor of a 'non-nucleoside' mechanism of antiviral action of substances (I) and (II). Two main hypotheses have been proposed: (1) introduction of the drug into the virion lipid membrane causing mechanical disturbance of its rheological properties, which, in turn, leads to inhibition of penetration of viral genetic material into the cell (of the act of fusion of virion and cell lipid membranes) [9-11]; (2) drugmediated photosensitized generation of singlet oxygen, oxidizing unsaturated lipids in virion membrane, which has no systems for membrane reparation [15]. Both hypotheses explain the broad spectrum activity of perylene derivatives against enveloped viruses, have consensus on the target (virion outer lipid membrane), and imply pharmacophoric importance of the perylene part of the molecule. Indeed, the carbohydrate fragment in such compounds is not a necessary precondition for antiviral activity. Recently, we have demonstrated the activity of a non-nucleoside derivative of cm1pUY11 (III) against enveloped viruses herpes simplex type 1 [11] and tick-borne encephalitis [14]. Thus, the lipid nature of the proposed antiviral target of perylene derivatives fundamentally distinguishes them from the three aforementioned groups of influenza drugs.

Ribonucleoside (IV) has not been previously described. Nor has the antiviral activity of perylene compounds, in relation to other respiratory viruses, been tested previously. The aim of this work was to synthesize the ribo derivative (IV) and to obtain data on the antiviral activity of compounds (I) - (IV) in relation to the influenza A virus and two other respiratory pathogens: type 3 parainfluenza virus and respiratory syncytial virus.

\section{RESULTS AND DISCUSSION}

Compound (IV) was prepared in four steps from uridine (V) (Scheme 1). Perylenylethynyl nucleoside derivatives have low solubility in most solvents, which makes it difficult to purify them using column chromatography. Therefore, acylic protection of hydroxyl groups of the carbohydrate fragment is usually applied, which allows to increase the solubility of the $s p-s p^{2}$ coupling product and to carry out its chromatographic purification after this step $[8,11,15,16]$. The isobutyryl group was chosen as such a protective group. Acylation of uridine with isobutyric anhydride resulted in 2',3',5'- $O$-acyl nucleoside (VI), which was further halogenated into a 5-iodo derivative (VII). The latter was alkynylated with 3-ethynylperylene under Sonogashira reaction conditions to afford a product (VIII), which had sufficient solubility for facile purification by means of silica gel column chromatography. To remove the protective groups, compound (VIII) was subjected to alkaline hydrolysis under mild conditions to yield the desired ribonucleoside rUY11 (IV). As with other perylenethynyl derivatives of nucleosides, compound (IV) is only slightly soluble in water but fairly soluble in DMSO. Solutions of compound (IV) feature the bright yellow-green fluorescence characteristic of perylenylethynyluracil derivatives. 


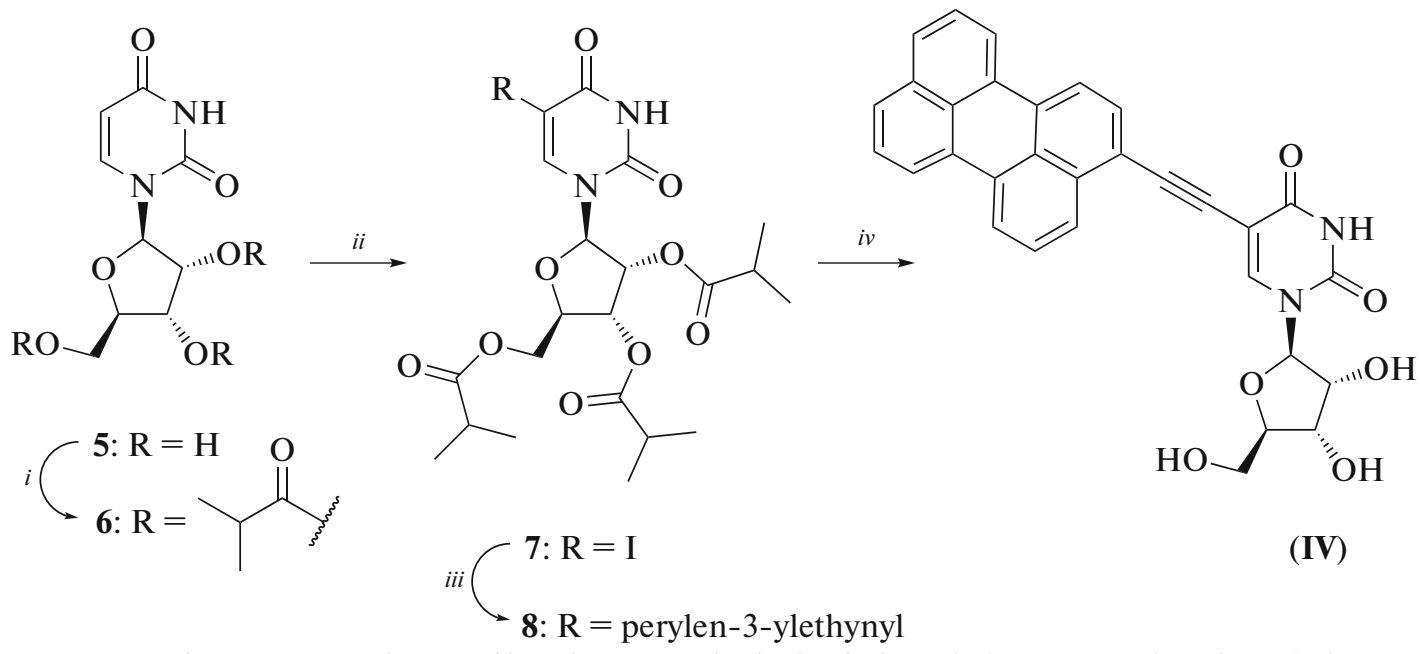

Scheme 1. Reagents and reaction conditions: $(i)$ isobutyric anhydride, 4-dimethylaminopyridine (DMAP), pyridine, $83 \%$;

(ii) iodine, ammonium-cerium(IV) nitrate (CAN), acetonitrile, $80^{\circ} \mathrm{C}, 93 \%$; (iii) 3-ethynylperylene, tetrakis(triphenylphosphine)palladium(0), copper(I) iodide, triethylamine, DMF, 78\%; (iv) potassium carbonate, methanol, $85 \%$.

For compounds (I) - (IV), antiviral activity was tested in vitro against influenza A, human parainfluenza type 3 , and respiratory syncytial virus. Data on their antiviral activity and cytotoxicity are given in Table 1.

It can be seen, from the data presented in Table 1, that the cytotoxicities of the preparations in both cell cultures were generally similar. At the same time, three of the four studied compounds feature low toxicity in cell cultures $\left(\mathrm{CC}_{50}\right.$ in the range 492-998 $\left.\mu \mathrm{M}\right)$, while the non-nucleoside compound cm1pUY11 (III) showed significantly more pronounced cytotoxic properties; this is probably due to the presence of the pivaloyloxymethyl group, which may hydrolyze to free pivalate, thus inhibiting L-carnitine metabolism in cells [17].

The $\mathrm{EC}_{50}$ values for all drugs were also similar and ranged from 0.5 to $7.1 \mu \mathrm{M}$, resulting in high selectivity index (SI) values. For all tested compounds, the SI was higher than the threshold value of 10, which allows considering a preparation promising for further studies, even despite the high values of $\mathrm{CC}_{50}$, as in the case of compound cm1pUY11.
Thus, all of the compounds used in this study can be characterized as having high antiviral activity against influenza, parainfluenza, and respiratory syncytial viruses when tested in vitro using cell cultures.

\section{EXPERIMENTAL SECTION}

All solvents and reagents were used without additional purification. 3-Ethynylperylene [8, 18], as well as compounds (I) [8], (II) [9, 19] and (III) [14], were synthesized as described previously. ${ }^{1} \mathrm{H}$ and ${ }^{13} \mathrm{C}$ NMR spectra were recorded with the Bruker Avance III $500 \mathrm{MHz}$ NMR spectrometer with signal attribution by residual proton peaks in solvents: $\mathrm{CDCl}_{3}(7.26 \mathrm{ppm}$ for ${ }^{1} \mathrm{H}$ and $77.16 \mathrm{ppm}$ for $\left.{ }^{13} \mathrm{C}\right)$; and DMSO- $d_{6}(2.50 \mathrm{ppm}$ for ${ }^{1} \mathrm{H}$ and $39.52 \mathrm{ppm}$ for ${ }^{13} \mathrm{C}$ ). ${ }^{1} \mathrm{H}$ NMR coupling constants are reported in Hertz $(\mathrm{Hz})$ for the respective multiplets. UV spectra were recorded using a Varian Cary 100 spectrophotometer. Fluorescence spectra were recorded using a Perkin Elmer LS 55 spectrometer. Thin layer chromatography was performed on TLC Silica gel $60 \mathrm{~F}_{254}$ (Merck) aluminum plates.

2', 3',5'-O-Triisobutyryluridine (VI). To a solution of uridine $(5.00 \mathrm{~g}, 20.48 \mathrm{mmol})$ and 4-dimethylamin-

Table 1. Antiviral activity and cytotoxicity of compounds I-IV in MDCK cell culture (IVA) and HEp-2 culture (PIV-3, RSV). SI-chemotherapy index (selectivity index), equal to $\mathrm{CC}_{50} / \mathrm{EC}_{50}$ ratio

\begin{tabular}{l|c|c|c|c|c|r|r|r|r}
\hline \multirow{2}{*}{ Compounds } & \multicolumn{3}{|c|}{ Influenza A virus (IVA) } & \multicolumn{3}{c}{$\begin{array}{c}\text { Human parainfluenza virus type 3 } \\
\text { (PIV-3) }\end{array}$} & \multicolumn{3}{c}{$\begin{array}{r}\text { Human respiratory syncytial virus } \\
\text { (RSV) }\end{array}$} \\
\cline { 2 - 9 } & $\mathrm{CC}_{50}, \mu \mathrm{M}$ & $\mathrm{EC}_{50}, \mu \mathrm{M}$ & $\mathrm{SI}$ & $\mathrm{CC}_{50}, \mu \mathrm{M}$ & $\mathrm{EC}_{50}, \mu \mathrm{M}$ & $\mathrm{SI}$ & $\mathrm{CC}_{50}, \mu \mathrm{M}$ & $\mathrm{EC}_{50}, \mu \mathrm{M}$ & $\mathrm{SI}$ \\
\hline dUY11 (I) & $492 \pm 56$ & $2.7 \pm 0.7$ & 180 & $598 \pm 44$ & $2.2 \pm 0.5$ & 270 & $598 \pm 44$ & $1.8 \pm 0.2$ & 330 \\
aUY11 (II) & $894 \pm 23$ & $5.2 \pm 0.4$ & 170 & $998 \pm 59$ & $1.3 \pm 0.3$ & 770 & $998 \pm 59$ & $2.3 \pm 0.1$ & 430 \\
cm1pUY11 (III) & $34 \pm 1.9$ & $0.50 \pm 0.02$ & 68 & $45 \pm 3.4$ & $4.3 \pm 0.2$ & 10 & $45 \pm 3.4$ & $1.9 \pm 0.1$ & 24 \\
rUY11 (IV) & $658 \pm 34$ & $6.4 \pm 1.2$ & 100 & $599 \pm 23$ & $2.9 \pm 0.4$ & 210 & $599 \pm 23$ & $7.1 \pm 0.2$ & 84 \\
\hline
\end{tabular}


opyridine $(20 \mathrm{mg})$ in dried pyridine $(35 \mathrm{~mL})$, isobutyric anhydride $(10.2 \mathrm{~mL}, 61.43 \mathrm{mmol})$ was added at once. The mixture was stirred at room temperature for $24 \mathrm{~h}$, diluted with methanol $(5 \mathrm{~mL})$, and evaporated in a vacuum. The residue was dissolved in dichloromethane $(200 \mathrm{~mL})$, and washed with saturated aqueous $\mathrm{NaHCO}_{3}(2 \times 150 \mathrm{~mL})$ and brine $(150 \mathrm{~mL})$. The organic phase was dried with $\mathrm{Na}_{2} \mathrm{SO}_{4}$, filtered, and evaporated in a vacuum. The residue was purified by column chromatography on silica gel $(0 \rightarrow 2 \%$ methanol in dichloromethane, (vol)), and compound (VI) $(7.72 \mathrm{~g}, 83 \%)$ was obtained as a white foam. $R_{\mathrm{f}} 0.65$ ( $n$-hexane-ethyl acetate, $1: 1$ (vol)). ${ }^{1} \mathrm{H}$ NMR $\left(500 \mathrm{MHz}, \mathrm{CDCl}_{3}\right): \delta 9.26(\mathrm{~s}, 1 \mathrm{H}), 7.42(\mathrm{~d}, J 8.1,1 \mathrm{H})$, $6.13-6.04(\mathrm{~m}, 1 \mathrm{H}), 5.77(\mathrm{~d}, J 8.2,1 \mathrm{H}), 5.33-5.28(\mathrm{~m}$, $2 \mathrm{H}), 4.42-4.26(\mathrm{~m}, 3 \mathrm{H}), 2.67-2.49(\mathrm{~m}, 3 \mathrm{H}), 1.26-$ $1.08(\mathrm{~m}, 18 \mathrm{H}) .{ }^{13} \mathrm{C}$ NMR $\left(126 \mathrm{MHz}, \mathrm{CDCl}_{3}\right): \delta$ 176.44, 175.83, 175.81, 162.93, 150.29, 139.23, 103.47, $87.16,80.53,72.86,70.23,63.32,34.11,33.86,33.79$, $19.10,19.05,18.97,18.88,18.82,18.80$.

2', 3',5'-O-Triisobutyryl-5-iodouridine (VII). Ammonium-cerium(IV) nitrate $(9.17 \mathrm{~g}, 16.72 \mathrm{mmol})$ and iodine $(2.49 \mathrm{~g}, 10.03 \mathrm{mmol})$ were added to a solution of compound (VI) $(7.60 \mathrm{~g}, 16.72 \mathrm{mmol})$ in dry acetonitrile $(210 \mathrm{~mL})$. The reaction mixture was stirred at $80^{\circ} \mathrm{C}$ for $1 \mathrm{~h}$ and evaporated in a vacuum. The residue was dissolved in ethyl acetate $(200 \mathrm{~mL})$ and washed with brine $(100 \mathrm{~mL})$. The organic phase was separated, washed with $5 \%$ aqueous $\mathrm{NaHSO}_{3}(100 \mathrm{~mL})$, dried over $\mathrm{Na}_{2} \mathrm{SO}_{4}$, filtered, and evaporated to dryness. The residue was purified by column chromatography on silica gel $(0 \rightarrow 1 \%$ methanol in dichloromethane (vol)), and compound (VII) $(9.00 \mathrm{~g}, 93 \%)$ was obtained as a white foam. $R_{\mathrm{f}} 0.75(n$-hexane-ethyl acetate, $1: 1(\mathrm{vol})) .{ }^{1} \mathrm{H} \mathrm{NMR}\left(\mathrm{CDCl}_{3}\right): \delta 9.16(\mathrm{~s}, 1 \mathrm{H})$, $7.86(\mathrm{~s}, 1 \mathrm{H}), 6.10(\mathrm{~d}, J 5.9,1 \mathrm{H}), 5.35-5.25(\mathrm{~m}, 2 \mathrm{H})$, $4.44(\mathrm{dd}, J 12.5,3.1,1 \mathrm{H}), 4.36(\mathrm{q}, J 3.0,1 \mathrm{H}), 4.30(\mathrm{dd}$, $J$ 12.5, 2.4, 1H), $2.74(\mathrm{p}, J 7.0,1 \mathrm{H}), 2.59(\mathrm{dp}, J 21.1$, 7.0, 2H), 1.26 (dd, $J 7.0,0.8,6 \mathrm{H}), 1.19$ (dd, $J 6.9,0.9$, $6 \mathrm{H}), 1.15(\mathrm{~d}, J 7.0,6 \mathrm{H}) \cdot{ }^{13} \mathrm{C} \mathrm{NMR}\left(\mathrm{CDCl}_{3}\right): \delta 176.49$, $175.84,175.80,159.69,149.99,143.63,86.89$, 80.96, $73.14,70.28,69.80,63.22,34.14,33.87,33.78,19.36$, $19.20,18.97,18.88,18.81,18.78$.

\section{2',3',5'-O-Triisobutyryl-5-(perylen-3-ylethynyl)uri-} dine (VIII). To a solution of protected iodide (VII) (280 $\mathrm{mg}, 0.48 \mathrm{mmol})$ and 3-ethynylperylene (177 $\mathrm{mg}$, $0.64 \mathrm{mmol})$ in dry DMF (13 mL), tetrakis(triphenylphosphine)palladium (67 mg, $0.058 \mathrm{mmol}$ ), copper(I) iodide $(22 \mathrm{mg}, 0.12 \mathrm{mmol})$, and triethylamine $(268 \mu \mathrm{L}, 1.93 \mathrm{mmol})$ were added. The flask was then evacuated and purged with argon three times successively. The reaction mixture was stirred at $35^{\circ} \mathrm{C}$ for $12 \mathrm{~h}$ and evaporated to dryness. The residue was dissolved in ethyl acetate $(30 \mathrm{~mL})$, washed with water $(20 \mathrm{~mL}), \mathrm{NaHCO}_{3}$ saturated water $(20 \mathrm{~mL})$, and brine $(20 \mathrm{~mL})$. The organic phase was dried over $\mathrm{Na}_{2} \mathrm{SO}_{4}$, filtered, and evaporated in a vacuum. The residue was purified by column chromatography on silica gel (toluene ethyl acetate), and compound (VIII) (273 mg, $78 \%$ ) was obtained in the form of brown foam. $R_{\mathrm{f}} 0.55$ (n-hexane-ethyl acetate, $2: 1$ (vol)). ${ }^{1} \mathrm{H}$ NMR $\left(\mathrm{DMSO}-d_{6}\right): \delta 11.96(\mathrm{~s}, 1 \mathrm{H}), 8.51-8.33(\mathrm{~m}, 4 \mathrm{H})$, $8.33-8.23(\mathrm{~m}, 2 \mathrm{H}), 7.90-7.78(\mathrm{~m}, 2 \mathrm{H}), 7.75-7.64(\mathrm{~m}$, $2 \mathrm{H}), 7.57(\mathrm{t}, J 7.7,2 \mathrm{H}), 5.98(\mathrm{~d}, J 4.6,1 \mathrm{H}), 5.63-5.51$ $(\mathrm{m}, 1 \mathrm{H}), 5.43(\mathrm{~s}, 1 \mathrm{H}), 4.37(\mathrm{~s}, 3 \mathrm{H}), 2.69-2.54(\mathrm{~m}$, $3 \mathrm{H}), 1.15-1.04(\mathrm{~m}, 18 \mathrm{H}) .{ }^{13} \mathrm{C}$ NMR (DMSO- $\left.d_{6}\right): \delta$ $175.79,174.94,161.38,149.32,143.73,134.21,133.84$, $131.43,131.06,130.60,130.09,129.79,128.76,128.42$, $127.93,127.81,127.62,127.06,127.02$, 125.72, 121.74, $121.49,121.38,120.34,119.19,99.26,91.13,88.22$, $88.01,79.48,72.50,69.39,62.71,33.22,33.07,18.79$, $18.69,18.62,18.54,18.51$.

5-(Perylen-3-ylethynyl)uridine (IV). One portion of saturated aqueous $\mathrm{K}_{2} \mathrm{CO}_{3}(2 \mathrm{~mL})$ was added to compound (VIII) solution $(250 \mathrm{mg}, 0.34 \mathrm{mmol})$ in pyridine $(2 \mathrm{~mL})$. The reaction mixture was stirred for $10 \mathrm{~h}$ at $45^{\circ} \mathrm{C}$ and diluted with water $(2 \mathrm{~mL})$. The precipitate was filtered off, washed three times (water $5 \mathrm{~mL}$, ethanol $2 \mathrm{~mL}$, diethyl ether $5 \mathrm{~mL}$ ), and dried in a vacuum to yield product (IV) (151 mg, 85\%) as a brown powder. $R_{\mathrm{f}} 0.40\left(\mathrm{CH}_{2} \mathrm{Cl}_{2}-\mathrm{MeOH}, 1: 1\right.$ (vol)). ${ }^{1} \mathrm{H}$ NMR $\left(500 \mathrm{MHz}, \mathrm{DMSO}-d_{6}\right) \delta 8.58-8.21(\mathrm{~m}, 6 \mathrm{H}), 7.82(\mathrm{~d}$, $J 7.7,2 \mathrm{H}), 7.74-7.61(\mathrm{~m}, 2 \mathrm{H}), 7.55(\mathrm{t}, J 7.8,2 \mathrm{H}), 5.84$ $(\mathrm{d}, J 4.2,1 \mathrm{H}), 5.70-4.93(\mathrm{~m}, 2 \mathrm{H}), 4.19-3.97(\mathrm{~m}, 2 \mathrm{H})$, $3.89(\mathrm{~d}, J 4.5,1 \mathrm{H}), 3.83-3.57(\mathrm{~m}, 2 \mathrm{H}) .{ }^{13} \mathrm{C} \mathrm{NMR}$ $\left(126 \mathrm{MHz}, \mathrm{DMSO}-d_{6}\right): \delta 143.53,134.15,133.71$, $130.81,130.58,130.14,129.99,129.89,128.35,128.15$, $127.73,127.67,127.56,126.90,126.87,126.04,121.31$, $121.26,121.06,120.24,120.19,98.81,98.09,89.76$, 88.94, 84.44, 73.94, 69.28, 60.41. UV (96\% EtOH, $\left.\lambda_{\max }, \mathrm{nm}\left(\varepsilon, \mathrm{M}^{-1} \mathrm{~cm}^{-1}\right)\right): 268(27800), 291(25000), 320$ (16400), 339 (16000), 369 (12800), 457 (18200), 513 (1600). Fluorescence $\left(96 \% \mathrm{EtOH}, \lambda_{\max }, \mathrm{nm}\right)$ (excitation $560 \mathrm{~nm}$ ): 239, 289, 363, 440, 514; (emission $490 \mathrm{~nm}$ ): 552.

\section{Measurement of Anti-Influenza Activity}

MDCK cell culture and influenza virus strain A/PR/8/34 (H1N1) were used in the study. Drugs were dissolved in DMSO $(2000 \mu \mathrm{g} / \mathrm{mL})$ and diluted in culture medium to a concentration corresponding to $\mathrm{CC}_{50}$ (the drug concentration causing $50 \%$ cell death). Following that, a series of 3-fold dilutions were prepared from this solution. A virus dilution (corresponding to multiplicity of infection (m.o.i.) $=1$ ) was prepared using culture media.

Cell cultures were washed with media, and experimental drug solutions $(100 \mu \mathrm{L}$ per well) were applied to them at the appropriate concentrations, followed by incubation for $1 \mathrm{~h}$ in the dark $\left(\mathrm{CO}_{2}\right.$ incubator, $37^{\circ} \mathrm{C}$, $5 \% \mathrm{CO}_{2}$ ). Virus (in a volume of $100 \mu \mathrm{L}$ ) was then added, followed by incubation for $24 \mathrm{~h}\left(37^{\circ} \mathrm{C}, 5 \%\right.$ $\mathrm{CO}_{2}$ ). At the end of the incubation period, 10-fold serial dilutions $\left(10^{-1}-10^{-7}\right)$ were prepared from each 
sample in support medium. These were applied to 1-day-old monolayers and then incubated for $72 \mathrm{~h}$ $\left(37^{\circ} \mathrm{C}, 5 \% \mathrm{CO}_{2}\right)$. Viral titers were determined by hemagglutination reaction. For this, culture medium was transferred to the appropriate wells of multi-well plates (U-bottom, immunology grade), and an equal volume of chicken red blood cell suspension ( $1 \%$ in physiological saline) was added. After 40 minutes, the presence or absence of hemagglutination in the wells was visually assessed. Viral titers were calculated using the Reed and Mench method [20] and expressed as 50\% tissue infection doses $\left(\mathrm{TID}_{50}\right)$ per $100 \mu \mathrm{L}$ volume. Drug antiviral activities were estimated based on decreased viral titers in relation to controls.

\section{Measurement of Antiviral Activity against Parainfluenza Virus and Respiratory Syncytial Virus}

HEp-2 cell culture, parainfluenza type 3 strain v2932, and respiratory syncytial virus A2 were used for analysis. Drugs were dissolved in DMSO $(2000 \mu \mathrm{g} / \mathrm{mL})$ and then in culture medium to a concentration corresponding to $\mathrm{CC}_{50}$. Next, a series of 3-fold dilutions were prepared from the initial solution. A series of 10fold virus dilutions $\left(10^{-1}-10^{-7}\right)$ was also prepared in a support medium.

Cell cultures were washed with medium, and drug preparations (in volumes of $200 \mu \mathrm{L}$ per well) were applied at the appropriate concentrations, followed by incubation for $1 \mathrm{~h}\left(37^{\circ} \mathrm{C}, 5 \% \mathrm{CO}_{2}\right)$. All culture media were then removed, and drug solutions were added to wells again $(100 \mu \mathrm{L}$ per well at twice the original concentration). Viral suspensions $(100 \mu \mathrm{L})$ were immediately added, and plates were incubated for $1 \mathrm{~h}\left(37^{\circ} \mathrm{C}\right.$, $5 \% \mathrm{CO}_{2}$ ). Plates were then washed free of virus, drug solutions were re-applied (at their original concentrations), and plates incubated for 6 days (at $37^{\circ} \mathrm{C}$, $5 \% \mathrm{CO}_{2}$ ).

Viral titers were determined using cellular immunoassay (cell-ELISA). For the analysis, cell cultures were fixed with cold $80 \%$ acetone for $15 \mathrm{~min}$ and washed with PBS-T buffer. Next, a solution of mouse primary antibodies (anti-parainfluenza virus $\mathrm{HN}$ protein) was applied and incubated for $2 \mathrm{~h}$ at room temperature with continuous stirring, followed by washing with buffer. Secondary antibodies were then applied and incubated again for $2 \mathrm{~h}$ with continuous stirring. The antibodies were washed out, and substrate-chromogenic mixture with 3,3',5,5'-tetramethylbenzidine (TMB) was applied. After $5 \mathrm{~min}$, reactions were stopped with $0.1 \mathrm{M}$ sulfuric acid, and optical densities of the solutions were measured at $450 \mathrm{~nm}$. Presence of infection was defined as sample optical densities exceeding those of the controls. Viral titers were calculated by the Reed and Muench method [20].

\section{Cytotoxicity Measurement}

For each compound, 2-fold serial dilutions were prepared (in culture media), starting from the original drug stocks in DMSO $(2000 \mu \mathrm{g} / \mathrm{mL})$. Cell cultures were washed with media, and drug $(100 \mu \mathrm{L}$ per well) was applied at the appropriate concentrations, followed by incubation for $24 \mathrm{~h}\left(37^{\circ} \mathrm{C}, 5 \% \mathrm{CO}_{2}\right)$. Cells were washed with PBS, and 3-(4,5-dimethylthiazol2-yl)-2,5-diphenyltetrazolium bromide (MTT) solution was applied $(0.5 \mu \mathrm{g} / \mathrm{mL}$ in culture medium), followed by incubation for 1.5 hours $\left(37^{\circ} \mathrm{C}, 5 \% \mathrm{CO}_{2}\right)$. MTT solution was removed, slurry was dissolved in 96\% ethyl alcohol, and optical densities of solutions were determined at $535 \mathrm{~nm}$ on a Wallas Perkin Elmer plate reader. Based on data analysis using GraphPad Prizm 5.0 software, $\mathrm{CC}_{50}$ values were determined.

\section{ACKNOWLEDGMENTS}

The work was supported by the Russian Science Foundation (RSF) grant no. 15-15-00053. A. A. Chistov was supported by a RF President's Scholarship (project SP4083.2018.4).

\section{COMPLIANCE WITH ETHICAL STANDARDS}

This article does not contain any research involving humans or animals as research subjects.

\section{Conflict of Interests}

The authors declare that there is no conflict of interests.

\section{NOTE ADDED IN PROOF}

During production of the article (December 2019-February 2020), mankind was faced with a sudden outbreak of acute respiratory illness (with significant mortality) caused by the SARS-CoV-2 enveloped coronavirus. Currently (28.02.20), COVID-19 has been recorded in many countries and is threatening to become a pandemic [21]. The unexpected emergence of the novel virus, and its rapid spread, further highlight the urgency of developing broadspectrum antiviral therapies targeting the lipid bilayer of enveloped viruses.

\section{REFERENCES}

1. Krammer, F., Smith, G.J.D., Fouchier, R.A.M., Peiris, M., Kedzierska, K., Doherty, P.C., Palese, P., Shaw, M.L., Treanor, J., Webster, R.G., and GarcíaSastre, A., Nat. Rev. Dis. Primers, 2018, vol. 4, article 3.

2. Iuliano, A.D., Roguski, K.M., Chang, H.H., Muscatello, D.J., Palekar, R., Tempia, S., Cohen, C., Gran, J.M., Schanzer, D., Cowling, B.J., Wu, P., Kyncl, J., Ang, L.W., Park, M., Redlberger-Fritz, M., Yu, H., Espenhain, L., Krishnan, A., Emukule, G., van Asten, L., Silva, S.P., Aungkulanon, S., Buchholz, U., Widdow- 
son, M.-A., and Bresee, J.S., Lancet, 2018, vol. 391, pp. 1285-1300.

3. Monto, A.S. and Fukuda, K., Clin. Inf. Dis., 2020, vol. 70, pp. 951-957.

4. Long, J.S., Mistry, B., Haslam, S.M., and Barclay, W.S., Nat. Rev. Microbiol., 2019, vol. 17, pp. 67-81.

5. Gubareva, L.V., Besselaar, T.G., Daniels, R.S., Fry, A., Gregory, V., Huang, W., Hurt, A.C., Jorquera, P.A., Lackenby, A., Leang, S.K., Lo, J., Pereyaslov, D., Rebelo-deAndrade, H., Siqueira, M.M., Takashita, E., Odagiri, T., Wang, D., Zhang, W., and Meijer, A., Antivir. Res., 2017, vol. 146, pp. 12-20.

6. Hauge, S.H., Dudman, S., Borgen, K., Lackenby, A., and Hungnes, O., Emerg. Inf. Dis., 2009, vol. 15, pp. 155-162.

7. van Dongen, M.J.P., Kadam, R.U., Juraszek, J., Lawson, E., Brandenburg, B., Schmitz, F., Schepens, W.B.G., Stoops, B., van Diepen, H.A., Jongeneelen, M., Tang, C., Vermond, J., van Eijgen-Obregoso Real, A., Blokland, S., Garg, D., Yu, W., Coutier, W., Lanckacker, E., Klap, J.M., Peeters, D.C.G., Wu, J., Buyck, C., Jonckers, T.H.M., Roymans, D., Roevens, P., Vogels, R., Koudstaal, W., Friesen, R.H.E., Raboisson, P., Dhanak, D., Goudsmit, J., and Wilson, I.A., Science, 2019, vol. 363, eaar6221.

8. Andronova, V.L., Skorobogatyi, M.V., Manasova, E.V., Berlin, Y.A., Korshun, V.A., and Galegov, G.A., Russ. J. Bioorg. Chem., 2003, vol. 29, pp. 262-266.

9. Vincent, M.R., Colpitts, C.C., Ustinov, A.V., Muqadas, M., Joyce, M.A., Barsby, N.L., Epand, R.F., Epand, R.M., Khramyshev, S.A., Valueva, O.A., Korshun, V.A., Tyrrell, D.L.J., and Schang, L.M., Proc. Natl. Acad. Sci. U. S. A., 2010, vol. 107, pp. 17339-17344.

10. Colpitts, C.C., Ustinov, A.V., Epand, R.F., Epand, R.M., Korshun, V.A., and Schang, L.M., J. Virol., 2013, vol. 87, pp. $3640-3654$.
11. Speerstra, S., Chistov, A.A., Proskurin, G.V., Aralov, A.V., Ulashchik, E.A., Streshnev, P.P., Shmanai, V.V., Korshun, V.A., and Shang, L.M., Antivir. Res., 2018, vol. 149, pp. 164-173.

12. Orlov, A.A., Chistov, A.A., Kozlovskaya, L.I., Ustinov, A.V., Korshun, V.A., Karganova, G.G., and Osolodkin, D.I., Med. Chem. Commun., 2016, vol. 7, pp. 495-499.

13. Hakobyan, A., Galindo, I., Nanez, A., Arabyan, E., Karalyan, Z., Chistov, A.A., Streshnev, P.P., Korshun, V.A., Alonso, C., and Zakaryan, H., J. Gen. Virol., 2018, vol. 99, pp. 148-156.

14. Chistov, A.A., Orlov, A.A., Streshnev, P.P., Slesarchuk, N.A., Aparin, I.O., Rathi, B., Brylev, V.A., Kutyakov, S.V., Mikhura, I.V., Ustinov, A.V., Westman, G., Palyulin, V.A., Jain, N., Osolodkin, D.I., Kozlovskaya, L.I., and Korshun, V.A., Eur. J. Med. Chem., 2019, vol. 171, pp. 93-103.

15. Vigant, F., Hollmann, A., Lee, J., Santos, N.C., Jung, M.E., and Lee, B., J. Virol., 2014, vol. 88, pp. 18491853.

16. Chistov, A.A., Ivanov, N.M., Kutyakov, S.V., Ustinov, A.V., Glybin, A.V., Streshnev, P.P., Mikhura, I.V., and Korshun, V.A., Tetrahedron Lett., 2016, vol. 57, pp. 4821-4823.

17. Brass, E.R., Pharmacol. Rev., 2002, vol. 54, pp. 589-598.

18. Chistov, A.A., Kutyakov, S.V., Ustinov, A.V., Aparin, I.O., Glybin, A.V., Mikhura, I.V., and Korshun, V.A., Tetrahedron Lett., 2016, vol. 57, pp. 1003-1006.

19. Chistov, A.A., Kutyakov, S.V., Guz, A.V., Mikhura, I.V., Ustinov, A.V., and Korshun, V.A., Org. Prep. Proced. Int., 2017, vol. 49, pp. 377-381.

20. Reed, L.J. and Muench, H., Am. J. Hygiene, 1938, vol. 27, pp. 493-497.

21. Cohen, J., Kupferschmidt, K., Science, 2020, vol. 367, pp. 962-963. 